\title{
Performance studies on millet processing machinery for tribal livelihood promotion
}

\author{
Dawn C. P. Ambrose ${ }^{1 *}$, S. J. K. Annamalai ${ }^{1}$, Ravindra Naik ${ }^{1}$, Anurag Kumar Dubey ${ }^{2}$ and \\ Subir Chakraborthy ${ }^{2}$
}

${ }^{1}$ Central Institute of Agricultural Engineering, Regional Centre, Coimbatore- 641007 (Tamil Nadu), INDIA

${ }^{2}$ Central Institute of Agricultural Engineering, Bhopal (Madhya Pradesh), INDIA

*Corresponding author. E-mail: dawncp@yahoo.com

Received: December 2, 2016; Revised received: March 20, 2017; Accepted: August 22, 2017

\begin{abstract}
A Millet Processing Centre for processing of minor millets in a tribal village in Tamil Nadu, has been established with the following millet processing machinery viz., Destoner, Millet Mill, Grain Polisher, Pulveriser, Flour Sifter and Packaging Machinery for enhancement of tribal livelihood. Performance studies on the machinery for processing minor millets viz., little millet, foxtail millet and finger millet grown in the tribal area were carried out. Based on the performance evaluation, the output capacity of destoner cum cleaner was found to be $230 \mathrm{~kg} / \mathrm{h}$ and $233 \mathrm{~kg} / \mathrm{h}$ for little and foxtail millet respectively with a cleaning efficiency of 89 and $90 \%$ respectively for the above millets. The performance of millet mill revealed that the output capacity was $90-92 \mathrm{~kg} / \mathrm{h}$ for little and foxtail millet with a dehulling efficiency of 86 and $87 \%$ respectively with small percentage of brokens $(<5 \%)$. The capacity of grain polisher was $60-61 \mathrm{~kg} / \mathrm{h}$ with a polishing efficiency of $85 \%$ \& $86 \%$ respectively for little and foxtail millet. The pulveriser was evaluated for finger millet flour making whereby the output capacity of the machine was $75 \mathrm{~kg} / \mathrm{h}$ with a milling efficiency of $90 \%$ respectively. The cost economics revealed that the tribal farmers could save $85 \%$ of the processing cost. The benefit cost ratio was found to be 2.05. The total profit to the tribal Society through Millet Processing Centre was Rs. 21,000/- during the first harvesting season of millets. The above studies have paved way for satisfactory functioning of the Millet Processing Centre in the tribal area.
\end{abstract}

Keywords: Cost economics, Millet processing machineries, Minor millets, Performance evaluation, Tribal farmers

\section{INTRODUCTION}

Millets are the basic cereals in India and eaten by a majority of the rural community. Minor cereals and other millets constitute a little less than 25 percent of the total food grain production in India. Besides being consumed as a staple food, millets are also the raw materials for the preparation of various food products. Millets are among the most nutritious food grains available in India and it is believed that people who consume millets on a regular basis categorically stay healthy. Millets are rich in calcium, fiber and glycemic index (Verma et al., 2013). They are rich source of vitamins and minerals. The dietary carbohydrate content of millets is also relatively high. Value addition in millets has great potential in increasing the profitability in cultivation. Nutritious millets are neglected in all respects including technology development for grain processing. There is no proper processing facility available at the production sites, despite India producing about 2 million tons of these grains. Due to the lack of processing technology, the rural farmers depend on the traditional methods which are dreary, drudgery and time consuming. This is also a reason for the decreasing popularity of these grains even among the traditional consumers (Bhag et al., 2010).

Millets, being small seeded and low price commodity, is not properly cleaned, graded and dried before they are brought to the markets, fetching low price to the farmers and poses storage problems. Presence of thick pericarp, pigments (dark seed coat of finger millet and pearl millet), certain phenolics, anti-nutrients and lack of secondary processing equipment's are the major hurdles that are preventing the widespread consumption of these crops and acceptance of food products of these commodities (NAAS, 2012).

Processing of the millets for many end uses involves primary processing operations viz., cleaning dehulling and milling operations. Being a staple product consumed at domestic levels, processing must be considered both at the production area and in industries (Amadou, 2013). Millets have not reached to the consumers on a wider level despite being nutritious, due to the confinement of processing and consumption at domestic level (Khamgaonkar, 2013). The tedious post -harvest operations along with the change in life styles in the rural areas, has discouraged the use of these millets in household consumption, particularly when there is access to alternative grains like rice, wheat or sorghum. Therefore, removal of drudgery in processing of 
millets could be eliminated by introducing easy-tooperate primary millet processing technology. Primary processing of millets involves the following unit operations viz., dehulling, destoning, cleaning, grading, milling and sifting.

The tribal area in the Western Ghats of Tamil Nadu is known for millets like finger millets, little millet and foxtail millet. There is no processing facility available in the hills and the tribal farmers travel across border to the neighboring state for processing of these millets. A Millet Processing Centre for processing millets in the tribal area, Aasanur, Tamil Nadu has been established and the performance of the millet processing centre was evaluated in terms of efficiency of the machinery and cost economics in order to promote the tribal livelihood and productivity in the selected tribal area under the study.

\section{MATERIALS AND METHODS}

Description of Millet processing centre: Millet Processing Centers are intended to facilitate primary and secondary processing of minor millets on rental/ payment basis to the tribal farmers. The center would procure and use the excess produce of a village or a cluster of villages and process the same by which income and employment to tribal people would be generated.

The Aadhimalai Pazhangudiyinar Producer Company which is a registered society run by the tribal farmers of 15 villages in and around Aasanur, Erode District, Tamil Nadu was identified for setting up the Millet Processing Centre (Fig. 1) in the tribal area where no such facility is available so far. The layout of the millet processing plant is provided in Fig. 2.

Description of millet processing machinery: The Millet Processing Centre consists of the following millet processing machinery viz., Destoner, Millet Mill, Grain Polisher, Pulveriser, Flour Sifter and Packaging Machinery etc.

Millet destoner: The machine is for removal of stone, impurities from small millets. The machine consists of deck of sieve of size 450 x $800 \mathrm{~mm}$, made of perforated dimple sheet for fluidization and effective separation with provision to adjust the inclination of the deck and outlet for cleaned grain and stones, an aspirator with centrifugal blower for removing light weight impurities, oscillating sieve box made of wood, $700 \mathrm{x}$ $1000 \mathrm{~mm}$ size to hold two sieves with sieve changing provision. It operates in a continuous mode powered by $1 \mathrm{hp} \mathrm{single} \mathrm{phase} \mathrm{electric} \mathrm{motor.}$

Millet mill: The machine is used for removing the outer husk of minor millets. It could be operated by a single phase electric motor. It consists of two abrasive rollers where dehusking takes place. The clearance between the surfaces could be adjusted for different millets. The unhusked millets are fed through a hopper which falls between the abrasive plates due to the centrifugal action. The dehulled grains are then collected through an outlet provided at the bottom. The husk and dust particles are collected in a cyclone separator.

Grain polisher: This is used for whitening or polishing of the dehulled millet grains. The machine operates on a continuous mode powered by $2 \mathrm{hp}$ single phase electric motor. The height of the machine is $1400 \mathrm{~mm}$.

Pulveriser: It is used for size reduction of minor millets into flour. It is a heavy duty machine, provided with hammers for pulverizing action. It consists of a grinding chamber provided with suitable lid/ cover and locking mechanism, sieve of ISS 40 of suitable size for mounting in the grinding chamber, cloth bag for easy collection of flour in to container. The power needed for operation of this machine is $7.5 \mathrm{hp}$ three phase motor with starter

Flour sifter: This is used for sieving/ sifting of flour in to two grades after pulverizing. It is provided with stainless steel mesh of 40 micron (ISS 40, ISS 70 and ISS 100) and provision for easy removal and fixing of sieves and cover to avoid spilling of feed and product. The outlets for fine and course materials are to be provided at appropriate height for ease of collection. It is operated by 2 hp single phase motor.

Performance studies of millet processing machinery: The millet processing machines were evaluated for their performance for foxtail millet, finger millet and little millet according to the standard procedure as below:

Cleaning efficiency: This is the ratio of cleaned grain to the total weight of the grain including impurities before cleaning and is expressed in percentage as below (Agidi Gbabo et al., 2015)

$\mathrm{C}_{\mathrm{E}}=\mathrm{W}_{\mathrm{c}} / \mathrm{T}_{\mathrm{w}} \times 100$

Where, $\mathrm{C}_{\mathrm{E}^{-}}$Cleaning Efficiency

$\mathrm{W}_{\mathrm{c}}$ - weight of cleaned millets, $\mathrm{kg}$

$\mathrm{T}_{\mathrm{w}}$ - total weight of millets before cleaning, $\mathrm{kg}$

Milling efficiency: Milling or dehulling efficiency of millet mill is expressed in percentage as the ratio of weight of milled grains to the total weight of the grains (unmilled) (Bisen et al., 2014)

$\mathrm{M}_{\mathrm{E}}=\mathrm{W}_{\mathrm{m}} / \mathrm{W} \times 100$

$\mathrm{M}_{\mathrm{E}}$ - Milling Efficiency, \%

$\mathrm{W}_{\mathrm{m}^{-}}$Weight of milled grains, $\mathrm{kg}$

$\mathrm{W}$ - total weight of grains, $\mathrm{kg}$

Broken rice recovery: Broken rice recovery is the amount of broken millet grains obtained during milling/dehusking and is expressed below (Adisa et al., 2016):

Broken millet rice, $\%=\mathrm{W}_{\mathrm{b}} / \mathrm{T}_{\mathrm{w}} \times 100$

$\mathrm{W}_{\mathrm{b}}$ - weight of broken millet rice, $\mathrm{kg}$

$\mathrm{T}_{\mathrm{w}^{-}}$total weight of dehusked millets (broken+whole grains), $\mathrm{kg}$

\section{Polishing efficiency}

$\mathrm{P}_{\mathrm{E}}=\mathrm{W}_{\mathrm{p}} / \mathrm{W} \times 100$

Where PE- polishing efficiency, $\%$

$\mathrm{W}_{\mathrm{p}}$ - weight of polished grains, $\mathrm{kg}$

$\mathrm{W}$-total weight of grains, $\mathrm{kg}$ 


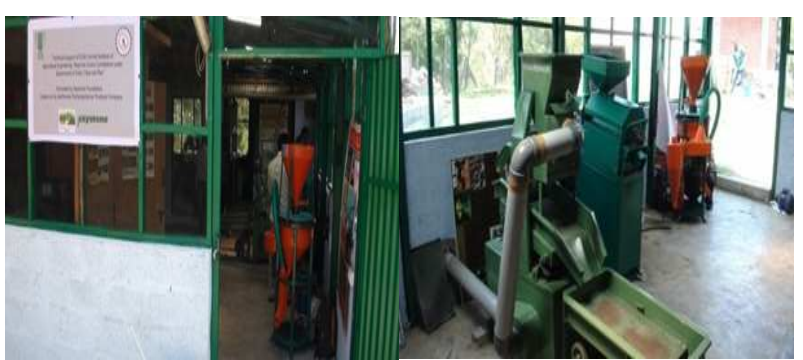

Fig. 1. Millet processing centre in tribal area, Aasanur Tamil Nadu.

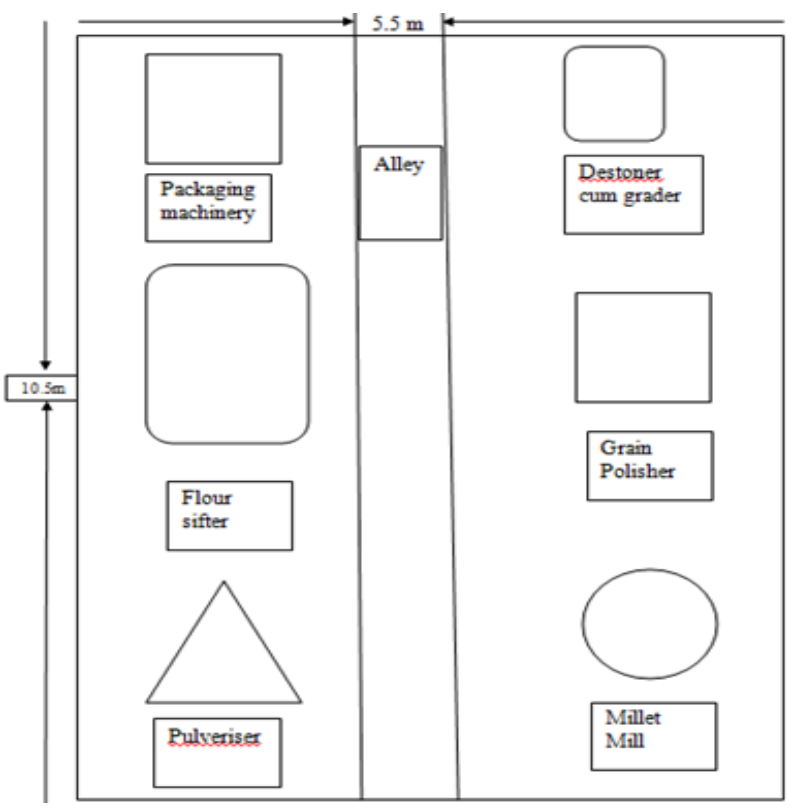

Fig 2. Layout of millet processing machinery.

Pulverising efficiency: Pulverising efficiency was calculated based on the ratio of millets pulverized into flour to the total weight of millets fed into the pulveriser (Tunde \& Samson, 2014)

$\mathrm{P}_{\mathrm{E}}=\mathrm{W}_{\mathrm{f}} / \mathrm{T}_{\mathrm{w}} \times 100$

$\mathrm{P}_{\mathrm{E}^{-}}$Pulverising Efficiency

$\mathrm{W}_{\mathrm{f}^{-}}$weight of millet flour

$\mathrm{T}_{\mathrm{w}}$ - total weight of millets

Machine capacity: This is the quantity of the millet processed in the machine per unit time. Mathematically expressed as

$M c=Q / t m$

Where, $M c$ is the machine capacity,

$\mathrm{Q}$ is the quantity taken to process

$\mathrm{tm}$ is the time for operation

Training on millet processing machinery in the tribal area: The members of Millet Processing Centre Committee were given training on the operation of millet processing machineries installed in the tribal area (Fig. 3). They were also exposed to making value added products from millets viz., millet biryani mix, milet tomato rice mix, millet pongal rice mix, millet cookies etc. as an expansion activity of the centre.

Cost economics: The cost economics of the Millet Processing Centre, in terms of cost of processing per

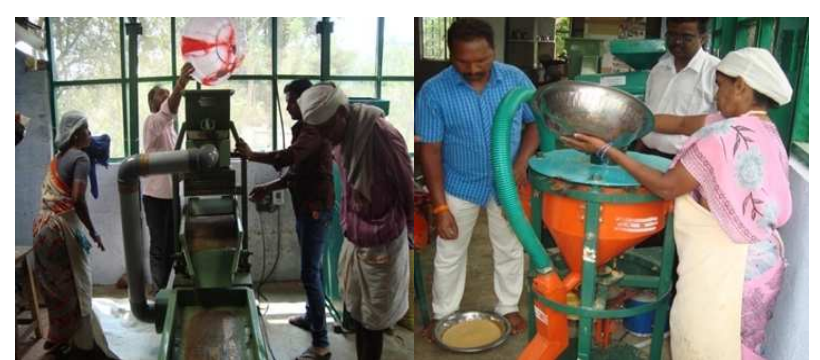

Fig. 3. Hands on training on operation of millet processing machineries.

$\mathrm{kg}$ of millets, net revenue, \% savings in cost etc. were worked out according to the following formula.

Total cost, Rs. $=$ Fixed cost + Variable cost

Cost of processing, Rs. $=$ Total cost $/ \mathrm{kg}$

Net revenue, Rs. $=$ Total revenue- total cost of operation

\section{RESULTS AND DISCUSSION}

Performance studies on millet processing machineries: The millet processing machineries were evaluated for their performance after installation. The efficiency and the actual capacity were calculated under each trial (Table 1).

The millet grains viz., foxtail millet and little millet were cleaned using destoner. The cleaning efficiency for little millet and foxtail millet was 89 and $90 \%$ respectively. The overall efficiency for cleaning paddy was reported as 50-71\% (Okunola et al., 2015). The capacity of the destoner was tested for its actual capacity and was found to be $230 \mathrm{~kg} / \mathrm{h}$ for little millets and $233 \mathrm{~kg} / \mathrm{h}$ for foxtail millet. Similarly the millet mill was evaluated for its performance for dehulling foxtail and little millet and was reported as $86 \%$ and $87 \%$ respectively. Adegun et al. (2012) reported that for lesser feeding rate of paddy, the dehulling percentage was 80 which reduced considerably at higher feeding rate. The percentage of brokens during dehulling was found to be less $(<5 \%)$. It has been reported by Gbabo and Ndgagi, (2014) that with lower feed rate, the percentage of brokens was less for paddy grains. The capacity of millet mill was found to be $90 \& 92$ $\mathrm{kg} / \mathrm{h}$ for little millet and foxtail respectively. The dehulled millet grains were subjected to polishing. The percentage polishing was $85 \& 86 \%$ respectively for little and foxtail millet with actual capacity of $60 \& 61$ $\mathrm{kg} / \mathrm{h}$. Millets like finger millet are consumed in the form of flour for porridge making and for the production of malted drinks. Hence the finger millet was converted into flour using the pulveriser. It was found that the milling efficiency was found to be 90 for finger millet. The capacity of the pulveriser was $75 \mathrm{~kg} / \mathrm{h}$ for making finger millet flour. Earlier studies on finger millet flour using an attrition mill revealed that at 0.3 $\mathrm{mm}$ plate clearance, $100 \mathrm{~kg} / \mathrm{hr}$ feed rate and $600 \mathrm{rpm}$ plate speed combinations; milling efficiency of the attrition mill was 85 per cent (Shankar et al., 2013). 
Table 1. Performance of Millet processing machineries.

\begin{tabular}{lccc}
\hline Product & Machinery & Parameters & Actual capacity, kg/h \\
\hline Little Millet & Destoner & $89 \%$ cleaning efficiency & 230 \\
Foxtail Millet & Destoner & $90 \%$ cleaning efficiency & 233 \\
Little Millet & Millet mill & $87 \%$ milling efficiency & 90 \\
Foxtail Millet & Millet mill & $86 \%$ milling efficiency & 92 \\
Little Millet & Polisher & $85 \%$ polishing efficiency & 60 \\
Foxtail Millet & Polisher & $86 \%$ polishing efficiency & 61 \\
Finger Millet & Pulveriser & $90 \%$ milling efficiency & 75 \\
\hline
\end{tabular}

Table 2. Cost economics of Millet processing centre.

\begin{tabular}{|c|c|c|c|c|}
\hline Activity & $\begin{array}{l}\text { Little millets -cleaning } \\
\text { +dehulling, kg }\end{array}$ & $\begin{array}{l}\text { Foxtail millet- cleaning } \\
\text { +dehulling, kg }\end{array}$ & $\begin{array}{l}\text { Finger millet } \\
\text { dehulling, } \mathrm{kg}\end{array}$ & $\begin{array}{l}\text { Finger millet } \\
\text { flour, kg }\end{array}$ \\
\hline Total quantity processed, $\mathrm{kg}$ & 3010 & 2382 & 2520 & 373 \\
\hline Processing charges, Rs./kg & 6 & 6 & 3 & 3 \\
\hline Total Revenue & 18060 & 14292 & 7560 & 1119 \\
\hline Cost of operation, Rs./kg & 2.9 & 2.9 & 1.50 & 1.64 \\
\hline Total cost of operation, Rs & 8729 & 6908 & 3780 & 612 \\
\hline Net profit & 9331 & 7384 & 3780 & 507 \\
\hline Total profit & 21002 & & & \\
\hline Benefit cost ratio & 2.05 & & & \\
\hline \multicolumn{5}{|l|}{ Benefit to tribal farmers } \\
\hline $\begin{array}{l}\text { Processing }+ \text { transportation } \\
\text { charges, Rs. (outside) }\end{array}$ & $6+16=22$ & 22 & 19 & 19 \\
\hline Total Processing charges, Rs. & 63822 & 51524 & 47386 & 7087 \\
\hline Savings in cost, $\%$ & 86 & 86 & 84 & 84 \\
\hline
\end{tabular}

Entrepreneurship development: The Millet Processing Centre at Aasanur, Erode Dt. of Tamil Nadu has been used both by the tribal producer company as well as the tribal farmers for their individual household consumption. A similar entrepreneurship development study for rural youth has been conducted for turmeric processing in the production catchment of turmeric at Sangampalayam village, Coimbatore District, Tamil Nadu (Dawn et al., 2013). Based on the processed raw material, the tribal producer company has expanded their millet processing activities in the production of value added ready to eat millet products viz., biriyani mix, sambar rice mix, pongal mix, tomato rice mix etc. Also they have started the production of millet cookies from the cleaned and processed millets from the millet processing centre. The tribal farmers have so far processed $2382 \mathrm{~kg}$ of foxtail millet, $3010 \mathrm{~kg}$ little millet (cleaned and dehulled), $2520 \mathrm{~kg}$ finger millet dehulled and $373 \mathrm{~kg}$ finger millet flour production during the first season of millets using the facility of millet processing centre.

Cost economics: The cost economics of the Millet Processing Centre using different machine were worked out (Table 2). The cost of operation for each unit operation during processing was found out to calculate the net returns of the Millet Processing Centre. The operational charges for millet rice from little and foxtail millet was found to be Rs. $2.9 / \mathrm{kg}$ whereas the operational cost for cleaning and pulverizing finger millet was Rs. $1.5 / \mathrm{kg}$ and Rs. $1.64 / \mathrm{kg}$ respectively. The tribal farmers could save a major portion of cost by way of saving the transportation charges thereby saving on an average of $85 \%$ in cost for processing using the millet processing centre facility.

The revenue generated through Millet Processing Centre was about Rs. 41031/- with a net profit of Rs. 21000/ during the first season of millets using MPC. In addition, the revenue has been increased through the production of value added products viz., millet rice mixes and millet cookies by the tribal farmers.

\section{Conclusion}

The millet processing machinery at Millet Processing Centre, established in the tribal area of Tamil Nadu were evaluated for their performance for little mallet, foxtail millet and finger millet respectively. The cleaning efficiency of the destoner was found to be around $88 \%$ and the highest dehulling efficiency was $90 \%$ for little millet. The pulverizing efficiency of the pulveriser was $90 \%$ as tested for finger millet. The cost economics of the Millet Processing Centre for tribal promotion was worked out and it was found that the tribal farmers could save $85 \%$ of processing cost through the millet processing machinery. The performance studies on the millet processing machinery have led to the proper functioning of the Millet processing centre for the tribal betterment.

\section{REFERENCES}

Adegun, I.K. Adepoju, S.A. and Aweda, J.A. (2012). A mini rice processing machine for Nigerian farmers. Journal of Agricultural Technology, 8(4): 1207-1216

Adisa A. Folami, Eberendu N. Obioha, Aderinlewo A. Adewole, Kuye S. Ibiyemi. (2016). Performance evaluation of a developed rice-processing machine. Journal of Agricultural Engineering, 47:171-176 
Agidi Gbabo1, Ndagi Baba, Kuku Alhassan Mohammed and Abdullahi Lukman. (2015). Development and Testing of a Rice Destoning Machine. Int. J. Engg. Res. \& Sci. \& Tech., 4(3): 134-141

Amadou, I. and Le MEGaG. (2013). Millets: Nutritional composition, some health benefits and processing - A Review. Emir. J. Food Agric., 25(7): 501-508

Bhag Mal, Padulosi, S. and Bala Ravi, S. (2010). Minor Millets in South Asia: Learning from IFAD-NUS Project in India and Nepal. Bioversity International, Maccarese, Rome, Italy and the M.S. Swaminathan Research Foundation, Chennai, India, pp 185

Bisen, R.M. Ramawat, R.B. Khope, P.B. and Choudhary, P.S. (2014). Design, Development and Performance Evaluations of Mini Rice Mill for Domestic Purpose. International Journal of Engineering Research \& Technology, 3(10): 1291-1294.

Dawn C.P. Ambrose, Muthamil Selvan and Annamalai, S.J.K. (2013). Techno-economic feasibility of Agro Processing Centre on custom hiring of primary processing equipment for turmeric by rural youth group. Madras Agric. J., 101(4-6):163-166

Gbabo A.and Ndagi B. (2014). Performance Evaluation of a Ricemill Developed in NCRI. International Journal of Engineering Research, 3(8):
$482-487$

Khamgaonkar, S.G. Singh, A. Khan Chand, Shahi, N.C. and Lohani, U.C. (2013). Processing technologies of Uttarakhand for lesser known crops: An overview. J Acad. Indus. Res., 1(8): 447-452

NAAS 2012. Integration of Millets in Fortified Foods. Policy Paper No. 54, National Academy of Agricultural Sciences, New Delhi.15 p

Okunola, A.A. Igbeka, J.C. and Arisoyin, A.G. (2015). Development and Evaluation of a Cereal Cleaner. Journal of Multidisciplinary Engineering Science and Technology, 2(6): 1587-1592

Shankar, M. Chowde Gowda, M. Manikandan, R. Usha Ravindra and Honabyraiah (2013). Performance Evaluation of Attrition Mill Used In The Finger Millet Processing Industries. International Journal of Technical Research and Applications, 1(5):59-62

Tunde I. Ogedengbe and Samson O. Abadariki (2014). Development and Performance Evaluation of a BoneMilling cum Pulverising Machine. The West Indian Journal of Engineering, 37(1): 23-28

Verma, V. and Patel, S. (2013). Production Enhancement, Nutritional Security and Value Added Products of Millets of Bastar Region of Chhattisgarh. Int. J. Res. Chem. Environ., 3(2): 102-106 